\title{
TTR
}

Traduction, terminologie, re?daction

\section{Rewriting Representations of the Foreign: the Ireland of Finnish Realist Drama}

\section{Sirkku Aaltonen}

Volume 9, numéro 2, 2e semestre 1996

Parcours de traduction

Pathways of Translation

URI : https://id.erudit.org/iderudit/037260ar

DOI : https://doi.org/10.7202/037260ar

Aller au sommaire du numéro

\section{Éditeur(s)}

Association canadienne de traductologie

ISSN

0835-8443 (imprimé)

1708-2188 (numérique)

Découvrir la revue

Citer cet article

Aaltonen, S. (1996). Rewriting Representations of the Foreign: the Ireland of Finnish Realist Drama. TTR, 9(2), 103-122. https://doi.org/10.7202/037260ar

\section{Résumé de l'article}

La réécriture des représentations de l'étranger: L'Irlande du théâtre réaliste finnois - Dans cet article, l'auteur étudie ce qu'il advient des éléments des milieux culturels dans la traduction du théâtre réaliste. À la suite des polysystémistes, l'hypothèse avancée est que la traduction des éléments du milieu implique une acculturation, ou une manipulation, même si le réalisme en tant que style de présentation professe l'imitation de la vie. Les éléments acculturés et la manière dont est réalisée l'acculturation sont liés à la connaissance présumée chez le public récepteur des conventions culturelles et génériques, ainsi que des fonctions théâtrales dont sont investis les éléments culturels spécifiques mis en scène et la construction de l'intrigue, le thème et l'atmosphère. À partir d'un corpus de huit pièces irlandaises réécrites en finnois, l'auteur en arrive à la conclusion qu'il faut les considérer comme des produits du système théâtral finlandais et non pas irlandais.
Tous droits réservés (C) TTR: traduction, terminologie, rédaction — Les auteurs, 1996
Ce document est protégé par la loi sur le droit d'auteur. L'utilisation des services d'Érudit (y compris la reproduction) est assujettie à sa politique d'utilisation que vous pouvez consulter en ligne.

https://apropos.erudit.org/fr/usagers/politique-dutilisation/ 


\section{Rewriting Representations of the Foreign : the Ireland of Finnish Realist Drama}

\section{Sirkku Aaltonen}

In the present article, I propose to discuss what happens to culturespecific elements in the transiation of realist drama ${ }^{1}$. The focus is on the ways in which translations of drama into Finnish have constructed their representations of Irish milieux and the implications of various translational strategies for dramatic functions. My hypothesis is that translation of such elements always involves acculturation, or manipulation, even though realism as a style of presentation professes to be "lifelike." Acculturation is needed to blur the borderline between the familiar and unfamiliar and to effect vraisemblance ${ }^{2}$ - integration between one discourse and another on the level of the socially familiar text, of our cultural stereotypes

1. This article is based on my doctoral thesis, Acculturation of the Other (1996), published by Joensuu University Press (available through St. Jerome Publishing, Manchester, England).

2. We can assume that the integration process follows certain cultural and literary/theatrical models, of which Culler (1975, pp. 140-152) has distinguished five. These five levels of vraisemblance are the ways in which a text may be brought into contact with and defined in relation to other texts. Although Culier has described naturalization processes in literature in general, I consider his description to apply to specific instances of translation as well. 
or accepted knowledge, and of the conventions of the genre and/or other texts we know. Which elements are acculturated, and how, is linked to the awareness which can be assumed on the part of the audience as regards cultural and generic conventions as well as dramatic functions of the culture-specific elements in characterization and the construction of plot, theme and atmosphere. My intention is not to evaluate the transiations, nor to speculate about the intentions of the translators. Instead, I have directed my attention to the dramatic implications of their choices. The reference material consists of rewritings of Irish twentieth-century plays (by Synge, $O^{\prime}$ Casey, Behan and Friel) produced in the Finnish theatrical polysystem between 1942 and $1983^{3}$. The plays form about one fourth of all the full-length Irish plays which have been rewritten ${ }^{4}$ in Finland.

\section{Translation for the Stage}

The focus in the analysis of the Irish milieux is directed towards the systemic market place, the theatre, in which a translator's discourse becomes standardized. The assumption is that regularities in the ways different aspects of the milieu are rewritten imply the existence of some consensus within the theatrical polysystem as to required translational behaviour. The theoretical framework which is applied

3. The empirical material for the analysis consists of the source texts and translations of eight Irish play texts completed in the Finnish theatrical polysystem between 1942 and 1983 . See Appendix for a list of these plays and their translations.

4. The term rewriting in the title expresses hesitation at separating translation from other forms of creative writing. At least in the theatrical polysystem, the borderline between a "translation" and an "original" may sometimes get very blured. Besides, the genetic specificity of all dramatic texts includes as one gene the existence of an "original" which is only more casily locatable for some than for others. In addition, the issue of originality is of minor importance in determining what the text will eventually grow into. Factors from elsewhere in the system decide on that. 
in the present analysis, and which I regard as among the most productive approaches to the study of translated drama, is polysystem theorys. It sees texts as elements in systems which govern the production and consumption of these texts through system-specific norms and conventions. Norms and conventions determine how texts come to be written and translated and which texts become accepted or rejected by the system.

The theatrical polysystem consists of texts and the agents who consume and produce them; it is a complex network of subsystems, mainstream and fringe theatres, and various producer and consumer systems. The producers include all those who contribute to the creation of texts in the polysystem, such as playwrights, translators, stage directors, costume designers, sound and light technicians, and actors. They produce texts which the spectators consume. However, as the theatrical polysystem is itself a subsystem, it is important that it does not upset the stability of the entire cultural polysystem. This is controlled from within the system by professionals - translators, artistic and stage directors, critics,

5. The two contemporary scholars who have developed the systems approach most fully are Itamar Even-Zohar and André Lefevere. I see their approaches as complementary in that Even-Zohar emphasizes intra-literary relations, whereas Lefevere concentrates on extra-literary links. In my view, it is important to see that literary or theatrical polysystems do not work in a vacuum but have close links with the surrounding socioeconomic polysystem. Even-Zohar introduced the polysystem theory in his works in 1969 and 1970, and developed it in a number of later studies. In 1990, he collected some of his earlier papers in an issue of Poetics Today. Lefevere also anticipated his main study of the systemic approach to literature in some earlier papers, notably in his article "Mother Courage's Cucumbers: Text, System and Refraction in a Theory of Literature" (Lefevere, 1982). Ten years later, his most comprehensive work on system theory was published under the title Translation, Rewriting \& the Manipulation of Literary Fame (1992). The discussion of the theatrical system in this article relies on the general outline of a literary system by Lefevere (1992). 
reviewers, anthologists - who contribute to the integration of a text into the theatrical, cultural and social polysystems. Patrons function outside the system, maintaining stability with an ideological, economic and status component; they include theatrical boards, the theatre union, and various municipal and state institutions, that is, elements which can further or hinder the reading, writing, and rewriting of texts. Throughout, considerations such as commercial and power-related factors are involved in the shaping of the systemic norms and conventions which define tolerated behaviour.

My choice of polysystem theory as the framework for the analysis implies doubts about the way in which traditional translation studies have in their methodology constructed the notion of fidelity to the "letter" and "spirit" of the "original" and then used these to make assessments of completed translations. I also challenge the concept of translations as self-evident mediators of clearly definable authorial intentions. I consider both assumptions to be very ambiguous, and therefore unreliable, as tools in translation studies. The power of individuals to inscribe their meaning on a text in such a way that it can be decoded unambiguously by other individuals, or the search for such a meaning, is a fallacy which has been challenged increasingly in recent years. The arguments about what the author-individual has "really meant" have been shown to be futile, because social and cultural changes have made it more and more difficult for people to read the world in even remotely similar ways. Moreover, texts may be reproduced in so many ways in such different conditions at different times that the whole idea of originality with its implications of superiority, must be questioned. Inferring the intentions of an individual author may also be misleading, as the originality of a play may be impossible to establish or may not be what we have assumed it to be. Originality and authorship are aspects of ownership, and their most important application at present is in the copyright laws ${ }^{6}$.

6. For a discussion of the status of writer-subjects as individuals, see Foucault (1977, pp. 124-131). 
Translation studies have traditionally relied on the assumption that the outcome of translational activity is determined by the source text and the translator's linguistic competence.Translation has been seen to be basically a linguistic activity: give any fool a dictionary and $s /$ he can do it. Our understanding of interaction between cultures has, however, shown that this is not the case, and any comparison of language systems will show great differences in the way they view the world. Translations always negotiate a compromise between two cultures, and they operate in a much wider context than the linguistic systems of the two texts. Translation is not primarily a linguistic operation.

For the purposes of the present analysis, I have identified the elements referring to the Irish milieu in the Finnish translations and divided them into the categories of geographical location, belief system, political concepts, art worlds, and contemporary life. I have also studied the language assumed to be spoken in the fictional world of the play in contrast to the language the dramatic figures actually use. As I have not attempted a statistical study, I have discussed the elements in as many sections as necessary. It is also worth remembering that individual concepts do not function alone, and that they are always supported by the context.

Culture-specific elements have different readings depending on the level of analysis: they function in the fictional world of the dramatic figures, but they are also needed for dramatic purposes between the stage and the audience. As such, they are related to the "observable reality" of the spectators, who ultimately provide readings for them on the basis of their experience of the world and their awareness of the conventions of the genre. My second step has therefore been to study these "facts" from the text in relation to the dramatic functions of plot, character, atmosphere and theme.

7. The term art world emphasizes that works of art are joint products of all those people who cooperate to produce works which that world, and perhaps others as well, define as art (Becker, 1982, pp. 34-35). 
Although spectators from the same cultural background may be able to agree on some basic content of the play, once passed the simplest denotational level, perceptions and interpretations begin to differ.

\section{Representations of Ireland in Finnish Translated Drama}

A convention exists in the Finnish theatrical system not to reset contemporary plays. This has not always been the case, and in the early history of Finnish theatre translation, total acculturation of the milieu was possible. Even today it is feasible to reset plays, as they are most often canonized classics whose copyrights have expired or do not constrain the resetting. However, within the initial norm of keeping the foreign milieu of contemporary plays intact, my analysis indicates that at least partial acculturation will always take place, following some general principles.

An Irish milieu is created in translated realist drama in three different ways. To begin with, proper names are among the most conspicuous tokens of the foreign, and because they are such recognizable links with observable reality, they create the sense that the text might be more documentary than fictional. The link with reality may be only imaginary, but it must correspond to the spectators' experience of observable reality. The spectators' theatrical competence sets the limits within which possible inconsistencies must occur in order not to be registered as disturbing. As a consequence, proper names, whether those of people or geographical location, are used in their foreign form and integrated into their Finnish contexts, with Finnish inflectional endings, partial translations or explanatory additions. Further, a group of foreign concepts is introduced as interculturalisms, that is, the names are translated even though the concepts themselves might remain unfamiliar. (Irlannin meri for The Irish Sea). The most

8. I use observable reality as an anatytical tool only. It must be viewed with the reservation that no reality exists beyond its representation, and the two are, in fact, inseparable. 
powerful features of the foreign are, however, cultural scripts ${ }^{9}$, as their influence extends beyond the level of individual words. For example, to a Lutheran, Catholicism is an integral part of the image of Ireland, and it forms almost without exception part of the lens through which Finns view Irishness. All but one of the central dramatic figures in my reference plays are Catholics, and religion forms an integral part of their everyday life; the Canon or the Father pays regular visits to his parishioners; religious authorities are constantly appealed to for help and support, and dramatic figures engage in daily prayers and regularly attend Mass. People take rosary beads with them wherever they go, and they all use religious exclamations.

Diachronically, there was some regularity in the way translations applied acculturation to certain subsystems of their culture-specific milieux. For example, in the 1942 translation of The Playboy of The Western World acculturation took the form of Finnish units of measurement, as well as some Finnish religious concepts and exclamations. Similarly, administrative units ${ }^{10}$, when

9. I use cultural script, modifying the definition by Andre Lefevere (1992, p. 89), to refer to the anticipated pattern of behaviour expected of people in certain situations in a certain culture. It is closely connected with cultural stereotypes or accepted knowledge in Culler's typology of the levels of vraisemblance.

10. In my analysis, I included administrative units under political concepts, which I defined as those which relate to the way social "reality" is organized. These concepts may imply or involve an ideological view or conviction of how society functions or should function, and of how it is run or should be run. They may also refer to the status quo of various social hierarchies. Political concepts thus include the names of groups which share an ideological interest and/or which may be more or less formally organized (such as feniaanit 'Fenians', kapinalliset 'rebels', tasavaltalaiset 'Republicans', IRA, Garda Siochana, Irlannin parlamentti 'Doyle [sic] Eireann'), references to historicallyspecifiable events (păsillisviikko 'Easter Week'), the emblems 
used figuratively, were either Finnish or neutral. However, the belief system of Catholicism came through in people's behaviour (cultural scripts), and this may have been the "local colour" referred to in the reviews of the productions.

In the 1960s, when a new translation of The Playboy of The Western World was commissioned, the acculturation was not so conspicuous. Instead, the milieu shifted towards the source text. The same translational behaviour, the use of elements of the foreign, was also visible in the translation of another play, The Hostage, which was commissioned in the same decade. In The Hostage, the units of measurement were foreign and so were newspapers, cigarettes and different kinds of drink. Furthermore, Aura ja tahdet (The Plough and the Stars), in 1964, followed the source text in transplanting the Irish political subsystem of organizations and ideologies into Finnish.

The trend of moderation in acculturation changed again in the eighties when the milieux were brought closer to Finnish audiences and vraisemblance became established on the level of familiar social discourse. By way of illustration, some of the drinking habits in Panttivanki (The Hostage) were made more Finnish in 1982 than they had been in 1962. Acculturation was, however, not applied to all sectors of the milieu: political concepts, for example, still closely followed those in the source text.

In all the above-mentioned cases, acculturation was effected mainly through the use of Finnish concepts in the plays' milieux. It is also possible to tone down the foreign through omission.

and symbols of a shared ideology ("Punainen kăsi" "the Red Hand', "Irlannin harppu ja apila" 'the Irish harp and shamrock', "Englannin leijona ja yksisarvinen" "the lion and the unicom of England', ".Auraja Tahdet" 'the Plough and the Stars'), the names of leaders (parnell, Larkin, de Valera), as well as administrative units (kreivikunta 'county', maakunta 'province', kihlakunta 'circuit of a judge'), and honorary titles (jaarli 'earl', herttua 'duke', lordi 'lord'). 
However, in my material, it was obvious that omission was used as a dramaturgical/structuraloperation and an explanation could always be found in that area. The culture-specific element was included in an "unnecessary" detail or scene which did not further the main plot or characterization. Overall, culture-specific elements were deleted in very few cases. They were deleted horizontally in details which could be regarded as superfluous to the main story line, and vertically when larger sections of the text were left out in order for the translation to highlight some point in the source text. Vertical deletion as well as the insertion of new lines or entire episodes are options in the theatrical polysystem, but only for those translators whom the polysystem has granted the power to effect them.

\section{Culture-Specificity and its Dramatic Functions}

If the study of the milieux is approached through the various categories of geographical location, belief system, political concepts, art worlds, and contemporary life, certain trends emerge which suggest regularities in translational behaviour. This behaviour may be a consequence of the foreignness of the element, but it may also be connected with its function.

A named geographical location may function on the level of the story, and the density with which specific localities are named in texts may vary from careful map-making to the mere indication of a possible locality. Place names may also characterize dramatic figures, either in self-presentation or in presentation by others, either explicitly or implicitly. The context usually supports a particular reading, as on their own the activation of any particular meaning would be more difficult. The names (in their contexts) may perform several functions simultaneously, and they may be central in one function, but still remain marginal to and not very prominent in the play as a whole.

The analysis of how Finnish translations have reacted to foreign placenames in the English source text revealed three translational strategies for all functions. The majority of placenames were integrated into the Finnish texts with inflectional endings or 
with explanatory nouns which appeared either as part of the name or as additions clarifying the reading of the placename. As was mentioned above, proper names could thus be read as providing necessary local colour. Another strategy which was applied to placenames was to delete them either horizontally or vertically, suggesting a dramaturgical decision to cut out a detail. The third strategy was to change the placename either to another or, was important if the placename was essential for the plot or characterization, to a generic word. There was, however, no obvious attempt to omit or acculturate foreign placenames. Difficulty in pronunciation did not appear to prompt omissions, which may be a consequence of the general cultural situation in Finland, where the culture of the English-speaking countries has become increasingly familiar over the years. Diachronic variation in creating foreign milieux through placenames was very small.

A particular political situation may be used to characterize dramatic figures and to establish a possible theme. Three plays in my reference material, Juno and the Paycock, The Plough and the Stars and The Hostage, take place at an identifiable moment in the history of Ireland, and the political situation is central to all three stories. In another play, Richard's Cork Leg, there are political concepts - the names of political leaders and organizations - which seem to function almost entirely between the stage and the audience. These concepts are only vaguely, if at all, tied to any dramatic function, and seem to have very little relevance to the scenes. In the Irish English version, this vagueness is further emphasized in the playscript by brackets, which indicate a theatre practitioner's opinion that the bracketed concepts could be left out outside Ireland.

The procedures applied to the translation of political concepts also followed a certain pattern. As with geographical placenames, one of the strategies was to leave proper names intact. With the names of organizations, a literal translation was used whenever possible. Translations which emphasized some aspect of the Irish concept were applied sparingly, and a totally different concept appeared hardly ever. A political concept was omitted entirely only if it was not necessary for an adequate understanding 
of the structure. Overall, translational solutions supported the analytical reading of the dramatic functions of the concepts and their contexts.

The religious belief system is at its most prominent in characterization, but it may also function as an element in the story or thematization.The Finnish translations constructed their representations of the Irish belief systems out of a mixture of foreign, neutral, and familiar concepts. Although foreign, Catholicism is not totally unknown to Finns, and there were therefore no particular problems in establishing an adequate understanding of the elements of the belief system, as there might have been if the cultural scripts had been more exotic. For example, the signs of Catholicism - the place of worship, the clergy, the rituals and exclamations - form part of the representation of Catholic Ireland and can easily be explained through their context. There are, however, some aspects of the belief system where the Irishness becomes neutralized.The Finnish plays do not, for example, always recognize the pervasive division of Irish society into two religious camps, the Protestant and Catholic, which becomes visible, say, in the difference between the places of worship (for example, the chapel and the church in The Plough and the Stars). Religious exclamations and a metaphorical use of religious concepts are also occasionally neutralized or Finnicized and the foreignness thus toned down.

A dramatic figure's competence in prestigious art worlds, expressed, for example, by taste or the ability to talk about them, functions primarily in characterization. For example, The Plough and the Stars takes place in the back drawing room of a tenement flat, on the wall of which hang copies of The Gleaners, The Angelus, and The Sleeping Venus. In a poor tenement flat, the fact that there are only copies of paintings on the walls and that the copies are of those particular popular paintings indicate a lower economic and social class. In addition to this, art worlds may also be used to suggest a desire to escape the limitations imposed by one's own (in my reference material, lower) social class. In Jumo and the Paycock, the daughter Mary is trying to gain cultural capital 
which belongs to another social class by reading books, while her father mocks her for doing that.

Similarities in perception of what constitutes "high culture" make the mainstream art worlds international to the extent that their foreignness or exotism is less significant than their indication of an individual's social and economic class. Although some may be nationally identifiable, both refined cultural goods and the more personal areas such as clothing, furniture, and cuisine identify people primarily as belonging to a certain class, and, perhaps, to a certain age group. They are thus among the many indicators of power in society at large.

As the most important function of art worlds was characterization, a range of translational procedures was available. The vraisemblance in the subsection of art worlds relied mostly on familiar social discourse and accepted knowledge in particular, as it was possible to deduce the relevant associations largely from the context in which a particular art world appeared. A precise recognition of an individual art world was hardly ever vital for an "adequate" understanding of the dramatic function it served. The art worlds indicate foreignness through the names of writers, their books, songs, places of production such as theatres, and so on. The only reference in my material to a specifically Irish art world is to an old Irish saga. In Juno and the Paycock, used in characterizing a dramatic figure, Captain Boyle exclaims in the English text that his wife ought really to be called Deirdre of the Sorrows because she is always complaining. It has been rewritten in the Finnish version as a biblical reference, Jeremian valitusvirsi, "lamentations of the prophet Jeremiah'.

The way Irish art worlds were transplanted into the Finnish translations was structurally (dramaturgically) justifiable. One of the most conspicuous alterations was deletion, vertical deletion in particular, when long stretches of text were probably not considered relevant for a particular understanding of the play. Deletion was often accompanied by changes in the order of the scenes or speeches. Vertical deletion and intersection as an overall approach 
to the English source text was at its clearest in the 1974 transiation of Purple Dust. Of the eighteen situations where references to oral or written culture appeared in the English Purple Dust, the 1974 translation deleted seven. The deletions ranged from individual remarks to entire exchanges between two dramatic figures.

Contemporary life shows in the settings, for example, in items of food and drink, the currency, and possibly some units of measurement, and the references vary in significance in individual plays. In some, such as The Hostage, drink in particular, is centrally present in almost all the scenes. The dramatic figures drink, or talk about drink, most of the time, and it is also an important element in the singing and dancing scenes, which, in a Brechtian manner, interrupt the flow of the story. The most important function of the references to food and drink are as elements of the story. Units of measurement and currency function as elements of the story and characterization, either in their concrete sense (the flour is packed in bags which hold a certain quantity; a baby weighs a certain amount; a distance is a precise number of miles, and so on) or in a metaphorical sense (see, for example, The Loves of Cass McGuire).

The everyday life of the dramatic figures comprises a collection of Finnish, Irish, and neutral elements. Specifically Finnish objects or concepts understandably occur very rarely, as the setting supposedly simulates Ireland, but in some plays the eating and drinking habits are very Finnish (for example in the 1981 version of The Hostage), which may indicate similarity between cultural scripts. It is more usual, though, that cultural scripts signal foreignness. This happens, for example, with the brand names of spirits. Different types of spirits - whiskey, gin, sherry, and brandy - are part of the western lifestyle, including Finland's, but the range of spirits available to different income groups varies between individual countries. Finland controls the consumption of alcohol through a pricing policy which up to the present has kept the prices of spirits relatively high. This means that although spirits are part of the Finnish socio-cultural setting, the use of certain brands in social situations is different from that in Irish society. They are not within everybody's reach, and the quantities bought at any one time cannot, 
for economic reasons, be very large either. Some income groups cannot afford to buy them at all. The consumption of these spirits in an ordinary everyday celebration in the Finnish versions of Richard's Cork Leg point, therefore, to a foreign cultural script. Items such as newspapers, medicine and units of measurement were often so different from each other, and their dramatic functions so varied, that finding any trends in their translation which could be generalized to all was practically impossible. The only patterns appeared in units of measurement and currency. Units of currency are almost without exception (the only exception in my material was the 1942 version of The Playboy of the Western World) used to signal the foreign, whereas in other measurements a mixture of Irish, Finnish and neutral units is quite common. Units of weight are most frequently Finnicized (a baby weighs a certain number of kilos rather than pounds and ounces), whereas distances, areas and temperatures function as symbolic Irish. In one of the plays (Brian Friel's Philadelphia, Here I Come), money is involved in the different cultural script of the method of payment for one's work. The most common Finnish paying arrangement is the salary, and the Finnish language does not distinguish between weekly wages and the monthly salary. Receiving weekly wages therefore signals foreignness. The translational procedures had, however, one thing in common: the Finnish translations supported an adequate understanding of the dramatic function, and the context helped the integration of the milieu.

\section{Dramatic Figures and Their Idiom}

In drama, the particular language, variety or accent that dramatic figures speak may serve a range of dramatic functions, or it may have very little, if any, dramatic significance. Within the fictional world of the play, a particular variety may be used consciously by a dramatic figure to demonstrate an ideology or opinion, or it may be used in an unconscious way, in which case its use may reveal something about the social or geographical background of the speaker. The language of the dialogue may distinguish between dramatic figures, or characterize all of them in relation to certain features which it is assumed the audience will recognize on the basis 
of comparison with observable reality, through the cultural vraisemblance of familiar social discourse, stereotypes or accepted knowledge, and through the audience's competence in theatrical conventions (of the genre as well as of the medium). In addition to its function within the dramatic structure of a play, a particular language variety or accent may also show the orientation of the playwright to given social norms, and s/he may articulate an existing social consensus by conforming to these norms or by trying to establish or break them.

Finnish translations reacted to Synge's Irish English with a variety of Finnish which followed the conventions of the contemporary Finnish theatre language, but did not - nor would it have been possible to - react to the social function Synge's language had in his time. The Finnish translations of O'Casey's plays used general colloquial speech. In the other plays in my study, no authorial social function was distinguishable.

On a few occasions, the plays used Gaelic for characterization. This was the case in The Hostage. The two Finnish translations, one from 1962 and the other from 1982, treated the Gaelic speeches differently. In the earlier translation, all the Gaelic was reduced to a few expressions which created the illusion of Irishness, whereas the later translation had the same Gaelic phrases as the English version. Both translations deleted individual Irish words when they had been used by dramatic figures whose characterization did not need them. In Panttivanki (The Hostage), Amerikantaddin rakkaudet (The Loves of Cass McGuire) and Juno ja riikinkukto (Juno and the Paycock), Gaelic was used by people who had not mastered it but for whom it was somehow important to do so. This reading was usually supported by the context. French was used in Richard's Cork Leg to characterize the Hero Hogan, and it was also transplanted into the Finnish translations as such. References to language varieties or accents in the authorial narrative were few, and their translations were significant only as guidelines for theatre practitioners. The language in drama is tied to a particular time and context, and elements which arise from contemperary circumstances are of interest in translations only as far 
as they have a dramatic function in the play. When linguistic specificity somehow needs to be distinguished, it can be done in a number of ways, ranging from token phrases to a total illusion supported by the situation. Theatrical conventions of authenticity as well as rhetorical conventions constrain choices both in the dialogue and the mise en scène.

\section{Cultural Specificity in Intercultural Theatre}

Inconsistency when foreign and Finnish elements are mixed revealed that what was assumed to cohere with observable reality only technically did so. The examples suggest that transiational solutions supported the dramatic functions of individual elements in the scenes. They showed that, if a concept served a dramatic function in the play and a decision had not been taken to ignore this function, an adequate reading would be secured by either the culture-specific element on its own, by its context, or by the two together. The translation would suggest a particular reading either through an explicit link with observable reality or through focusing on its associations. There were very few diachronic differences between different versions of the same play and translations completed at different points in time.

Cultural specificity is not foregrounded in intercultural theatre, and we do not go to see a play if its only attraction is its cultural specificity. The layer of general human concern often determines the attraction to foreign drama, and vraisemblance will have to take place on several levels before a translated play will interest foreign audiences. Audiences have to be able to relate to an unfamiliar reality, and cultural specificity will therefore need to be manipulated in such a way that there will be enough common ground in the play to understand it. Manipulation or acculturation is therefore one of the features of intercultural theatre, and what we take to represent the Foreign is often several removes from observable reality. This can best be illustrated by the many inconsistencies in the realist style of representation, which relies on the illusion that it is 'lifelike.' 
The focus in my study has been on the Finnish theatrical polysystem, into which translated drama has become integrated. Few dramatic texts in Finland ever enter the literary system, and it is often only canonized classics which are published in printed form. The translation of drama in Finland thus represents an intersection of the literary and the theatrical. While the source texts belong to the literary system in their own culture, when they are translated into Finnish they become integrated into another semiotic system, the theatre. The similarities between drama translation and the adaptation of novels as films are therefore often striking.

With some exceptions, the introduction of the plays in my study to Finnish theatre audiences followed general trends in Finnish intercultural theatre. The plays whose main function was seen to be to introduce of the work of well-known Irish playwrights such as Synge and $O^{\prime}$ Casey became integrated mainly with vraisemblance on the level of the genre (emotional or ethical realism), familiar social discourse, and accepted knowledge rather than empiricist realism, which would have relied heavily on coherence with Irish reality. "Strong local colour" was presented in the reviews as a negative trait, and the plays were seen as aiming at building on common features between Ireland and Finland. In the 1960s, the plays often combined political commentary and the cabaret tradition of songs, and the novelty of music presumably helped the integration. The plays in this study that were introduced in the eighties focused on the individual, not only in their fictional worlds but also outside it in the way they openly expressed the views of the playwright. New theatrical methods were tested, and the plays all broke the general illusionist convention in that they exposed the theatrical frame. Irishness was no longer central in the plays, and the playwright had largely lost his status as an exponent of an art world.

It is noticeable that those plays in my material which were closely connected with Irish society and its characteristics, such as the O'Casey Dublin trilogy, have not become rooted in the Finnish theatrical system, even though they have been very popular elsewhere. The flexibility of The Hostage may, on the other hand, 
explain its survival into the 1990s. Cultural specificity seems to work against integration. It may make some plays totally untranslatable, and tie others only very loosely, if at all, to the receiving system. Tolerance of foreignness may vary, and it may be connected with a great many factors in the theatre, including the general topicality of the source culture in the media at a given moment. It is likely that when a country or a nation features prominently in the news, some interest in its culture will be aroused as well. Irishness has stabilized its position in the Finnish awareness of the outside world to the extent that it has no novelty value at the moment. This may also work against cultural imports and explain why more recent Irish drama has not yet arrived on the Finnish stages. The integration and selection of drama for translation relies on the interest the receiving cultural polysystem feels for it, but how or whether this interest can be prompted will need considerable further research into the mechanisms of intercultural theatre. It is, however, clear that the need arises in the receiving system and is met by some aspects of the source text, while the source text has value only as far as it meets this need.

\section{University of Vaasa, Finland}

\section{References}

BECKER, Howard S. (1982). Art Worlds. Berkeley, University of California Press.

CULLER, Jonathan (1975). Structuralist Poetics. London and Henley, Routledge \& Kegan Paul.

FOUCAULT, Michel(1977). Language, Counter-memory, Practice. Transl, by D. F. Bouchard and S. Simon. Ithaca, Cornell University Press.

LEFEVERE, Andre (1982). "Mother Courage's Cucumbers: Text, System and Refraction in a Theory of Literature," 
(1992). Translation, Rewriting and the Manipulation of Literary fame. London, Routledge.

\section{Appendix}

- John Millington Synge (1907). The Playboy of the Westem World.

. Toivo Wallenius (1942). Läntisrannan kisapoika.

. Leif Forsblom (1969). Irlannin Hulivilipoika.

. A revision of Irlannin hulivilipoika for the production in Hämeenlinna town theatre in 1983 (an actor's copy).

- Sean O'Casey (1923). Juno and the Paycock.

. Arvi Kivimaa (1950). Juno ja riikinkukko.

- Sean O'Casey (1924-25). The Plough and and the Stars.

. Paavo Lehtonen (1964). Aura ja tahdet.

. A revision of Aura ja tahdet for the production in Turku town theatre in 1972 (the prompter's copy).

- Sean O'Casey (1939-40). Purple Dust.

. Paavo Lehtonen (1966). Purppuran tomua.

. Brita Polttila (1974). Purppuratomua.

- Brendan Behan (1958). The Hostage.

. Kirsti Jaantila (1962). Panttivanki.

. A revision of Panttivanki for a production in Oulou town theatre by the stage director Pentti Pesă in 1982.

- Brendan Behan (1972). Richard's Cork Leg.

(Alan Simpson, artistic director of the Abbey Theatre, cut and edited the drafts of the play which were found after Behan's death. For details, see Behan, 1958, pp. 8-10).

. Pentti Saarikoski (1983). Richardin korkkijalka.

- Brian Friel (1964). Phlladelphla, Here I Come.

. Pentti Saarikoski (1982). Tãaltä tullaan Amerikka. 
- Brian Friel (1966). The Loves of Cass McGuire.

. Pentti Saarikoski (1976). Amerikantaddin rakkoudet.

ABSTRACT: Rewriting Representations of the Foreign : the Ireland of Finnish Realist Drama - In this article, the author discusses what happens to culture-specific elements in the translation of realist drama. Following the polysystem approach, the hypothesis is that translation involves acculturation, or manipulation, even though realism as a style of presentation professes to be "lifelike." Which elements are acculturated, and how, is linked to the awareness assumed on the part of the audience of the cultural and generic conventions as well as of the dramatic function of the culture-specificelements in characterizationand the construction of plot, theme and atmosphere. Taking eight Irish plays rewritten into Finnish, the author concludes that they must be seen as products of the Finnish, not the Irish, theatrical system.

RtSUMÁ: La réécriture des représentations de l'étranger: L'Irlande du thétre réaliste finnois - Dans cet article, l'auteur étudie ce qu'il advient des éléments des milieux culturels dans la traduction du thếtre réaliste. A la suite des polysystémistes, l'hypothèse avancée est que la traduction des éléments du milieu implique une acculturation, ou une manipulation, même si le réalisme en tant que style de présentation professe l'imitation de la vie. Les éléments acculturés et la manière dont est réalisée l'acculturation sont liés à la connaissance présumée chez le public récepteur des conventions culturelles et génériques, ainsi que des fonctions théatrales dont sont investis les éléments culturels spécifiques mis en scène et la construction de l'intrigue, le thème et l'atmosphère. À partir d'un corpus de huit pièces irlandaises réécrites en finnois, l'auteur en arrive à la conclusion qu'il faut les considérer comme des produits du système théatral finlandais et non pas irlandais.

Sirkku Aaltonen : Department of English, University of Vaasa, P.O. Box 297, 25101 Vaasa, Finland.

E-mail: sirkku.aaltonen@uwasa.fi 